\title{
Investigation of the Relationship between E-Learning and Cooperative Learning Attitudes of High School Students
}

\author{
Namudar İzzet Kurbanoğlu*
}

\author{
Serhat Arslan**
}

\begin{abstract}
Individuals comprising the communities of today need to be have more knowledge, skills and talents in comparison with the past to keep up with the new age and maintain their lives. It is only possible to make the individuals get these information, skills and talents with the application of the methods related to the new teaching and learning processes. Pedagogical and technological improvements arousing in the late years both affect the human life deeply and most importantly learning and teaching fields. In addition, technology is considered to be very important in terms of educational processes that help individuals to solve problems encountered in life, pioneer scientific innovations and facilitate life in one part, as well as in school climate. The aim of this research is to investigate the relationships between e-learning and cooperative learning attitudes of the high school students. Attitude scales of e-learning and cooperative learning were utilized as a data collection tools in the research. The sample of the investigation comprises of 415 high school students from three schools in the province of Sakarya whom are 215 female and 200 male.The problem of the investigation was analysed by the use of "Pearson Moment Correlation" and "Structural Equation Model".Results show that there is a positive and significant relationship between the scores of students' e-learning attitude and the scores of students' cooperative learning attitude. Moreover, the findings gathered from Structural Equation Model demonstrate that coopeartive learning predicts positively the sub-dimensions of e-learning. These results were discussed in frame of the related literature.
\end{abstract}

Keywords: E-learning, cooperative learning, structural equation model

\footnotetext{
*Assoc. Prof. Dr., Sakarya University, Faculty of Education, Department of Science Education, Sakarya, Turkey.E-mail: kurbanoglu@ sakary a.edu.tr

** Assist. Prof. Dr., Sakarya University, Faculty of Education, Department of Education Science, Sakarya, Turkey.E-mail: serhatarslan@sakary a.edu.tr
} 


\title{
Lise Öğrencilerinin E-öğrenme Tutumları ile İşbirlikçi Öğrenme Tutumları arasındaki İlişkinin Belirlenmesi
}

\begin{abstract}
$\ddot{\mathbf{O} z}$
Günümüz topluluklarını oluşturan bireylerin, yeniçağa ayak uydurmak ve hayatlarını sürdürmek için geçmişle kıyaslandığında daha fazla bilgi, beceri ve yetenek sahibi olmaları gerekmektedir. Öğretim ve öğrenme süreçleri ile ilgili yeni yöntemlerin uygulanması ile bireylerin çağa uygun olarak bilgi, beceri ve yetenekleri elde etmelerini sağlamak mümkündür. Teknolojik alanda yaşanan baş döndürücü gelişmeler, hem insan yaşamını derinden etkilemekte hem de öğrenme ve öğretme süreçlerine farklı bir bakış açısı kazandırmaktadır. Ayrıca teknoloji, bireylerin yaşamda karşılaştığı problemlerin çözümüne yardımcı, bilimsel yeniliklere öncü ve yaşamı bir parça da olsa kolaylaştırmasının yanında okul ikliminde eğitimsel süreçler açısından da oldukça önemli olduğu kabul edilmektedir. Bu araştırmada; lise öğrencilerinin kendi kendine öğrenme sürecinde, e-öğrenmeye karşı tutumları ile işbirlikçi öğrenmeye karşı tutumları arasında anlamlı bir ilişkinin olup olmadığının belirlenmesi amaçlanmıştır. Araştırmada; veri toplama aracı olarak e-öğrenmeye yönelik tutum ölçeği ile işbirlikçi öğrenme ölçeği kullanılmıştır. Çalışmanın örneklemini, Sakarya ilinde üç farklı lisede öğrenim gören $215 \mathrm{klz}, 200$ erkek olmak üzere toplam 415 lise öğrencisi oluşturmaktadır. Araştırmanın problemi,"Pearson Moment Korelasyon" ve "Yapısal eşitlik modeli" ile analiz edilmiştir. Sonuçlar; öğrencilerin e-öğrenme tutum puanları ile işbirlikçi öğrenme tutum puanları arasında pozitif ve anlamlı bir ilişkinin olduğunu göstermiştir. Ayrıca, yapısal eşitlik modelinden elde edilen bulgular işbirlikçi öğrenmenin, e-öğrenmeye karş1

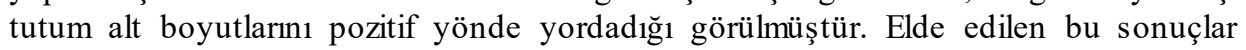
litaretür çerçevesinde tartışılmışıtır.
\end{abstract} modeli

Anahtar Sözcükler: e-öğrenme, işbirlikçi öğrenme, lise öğrencileri, yapısal eşitlik 


\section{Introduction}

Individuals comprising the communities of today need to be have more knowledge, skills and talents in comparison with the past to keep up with the new age and maintain their lives. It is only possible to make the individuals get these information, skills and talents with the application of the methods related to the new teaching and learning processes. Pedagogical and technological improvements arousing in tha late years both affect the human life deeply and most importantly learning and teaching fields (Kurbanoğlu, et al., 2010). The scientists who bring forward an idea about the definition and field of technology Goetsch, 1984; Middlehurst, 1999; Williams \& Kingham, 2003) identify the technology as an application of the solution to the problems, scientific norms and innovations, and as a life facilitator. They asserted that technology is an area including all the community and financial activities and organisations predicting the actualization of technical information (as cited in Erdemir, Bakurc1 \& Eyduran, 2009).In this context, the educators who support the entegration of technology to the teaching and learning process, believe that this entegration will provide learning and prepare the students for the professions of the 21. century (Butzin, 2000; Hopson, Simms \& Knezek, 2002; Reiser, 2001; Sam, Othman \&Nordin, 2005).

Until the second half of this century, learning and teaching environment in all countries comprised of teacher, textbooks and blackboard. Beginning from the second half of this century, the scientific and technological improvements provided the individuals to develop their self learning skills and talents (Bedard, 1997; Francis \& Flanigan, 2012). In the consideration of these developments, self learning has become an attractive field for the education of the individuals and in the theory (Hiemstra, 2004), and it has become an object of hundreds of articles, books and dissertations (Long, Redding \&Eisenman, 1994). Researchers suggested many definitions about self learning concept and skills in the related investigations.

According to Knowles (1975) and Pilling-Cormick, Garrison (2007), self learning is an approach in which the students take over responsibility for the necessary learning sources and the proper strategies compatible with their aims (Francis \& Flanigan, 2012). According to Russelland others (2007), self learning skills mean that the individuals take responsibility for their own learning skills, find the appropriate sources to the objectives and decide the methods for the evaluation of the learning (as cited in Aydede \& Kesercioğlu, 2012).Knowles (1975) emphasized that self learning approach will be a survival skill, and Candy (1991) asserted that self learning will develop individuals' critical thinking, understanding and decision making skills (Francis \& Flanigan, 2012).

Self learning or individual learning concepts have beenprimarilyinvolved as educational technology application to the educational literature with the terms like "programmed learning", "automatic learning" and "machine learning" since 1950s (Büyükkaragöz \& Çivi 1999; Hizal, 1977). Programmed learning is identified as an individual and self learning method that student involves in learning actively, improves oneself sistematically and provides constant control of learning. In this method, self learning tools are programmed books, charts, cassette tapes, films, teaching machines and so on (Büyükkaragöz\&Çivi, 1999). Popularity of personal computers, softwares, multimedia and computer networks encompassed the improvement and application of innovative teaching strategies and diversity of self learning tools with the development of computer technology.

Nowadays, methods like CD ROM application, web-based learning and mobile learning are benefited from computer technology in the self learning and teaching processes. Web based learning one of the computer assisted instructions is utilized not only in higher education but also at the high schools, middle schools and nursery-schools all over the world (Ghani, Hamim \& Ishak, 2007).Web based learning has developed significantly, constructed new learning environments and modified the teaching - learning styles since the improvements of world wide web. Web based learning mediates a student in anywhere to get information from a teacher somewhere else (Anderson, 2005; Lertlum \& Papasratorn, 2004; Angelini, et al., 2005). Therefore, web based learning facilitates students to access the information content without feeling a need any physical tools (Ghani, Hamim \&Ishak, 2007; Lertlum \&Papasratorn, 2004). Moreover, web based learning provides students to understand better by directing their attention to interesting and enjoyable subjects. Thereby, when a 


\section{INVESTIGATION OF THE RELATIONS HIP BETWEEN E-LEARNING AND COOPERATIVE LEARNING ATTITUDES OF HIGH SCHOOL STUDENTS}

student is asked to remember any information, the student can identify, explain and emphasize all the terms in the lesson (as cited in Kurbanoğlu, et al., 2010).

Recently, methods like CD-ROM application, web based learning and mobile learning has been identified as e-learning (Lertlum \& Papasratorn, 2006; Ghani, Hamim \& Ishak, 2007). E-learning can be supposed as an education system which can access to the all farther individuals with a web based wide communication nets (Halis, 2001; Aşkar, 2003). Generally, e-learning is accepted as utilization of internet and computer based technologies to facilitate education and teaching (Ruiz, et al.2006). However, thedefinition and scope of e-learning has changed with the development of technology. Nichols (2003) asserted a definition about this notion as utilization of different technological tools such as web based, distributed via web or web compliant to realize the education objectives. Waller (2001) describes e-learningas a productive learning process which is a content constructed to support self learning and converted into a digital media. The definitions about the e-learning above were produced related to combining, applying and relations of learning and teaching activities via different electronic environments. According to these definitions; e-learning, internet and web technologies which provide information transfer to many people in different times were utilized as basic components. Hence, awareness of pedagogical and technological dimensions of e-learning is very important in terms of improvement and application of technology based lessons. E-learning technologies can be applied in formal or informal education styles such as distance learning and open education. Moreover, some original components of e-learning can be utilized in different levels of both middle and higher education (Tuparova, et al., 2006).

Application of e-learning as a technique in process of self learning is bound up with self learning level of the students and internal compatibility ofteaching methods with each other. Long (1989) collocated individual difference variables of learner characteristic by emphasizing the role of learner characteristics in the self learning process as background information, attitudes, values, motivations, cognitive and emotional attributes. He asserted that these characteristics are precious demonstrations of that if an individual will interact with the learning constructs or not (Kasworm, 1992). Brockett and Hiemstra (1991) and Grow (1991) pointed out that different learning levels of the students in the formal education systems prevent the harmony among the applicated teaching methods (Francis \& Flanigan, 2012). In other words, it is emphasized that primary and middle schools systems managed by the educators prevent self learning tendency of the students (Eisenman, 1990; Kasworm, 1992; Piskurich, 1992). The lack of harmony between self learning and traditional learning methods was partially explained by experimential findings related to self learning and academical performance. In the researches, it was found that while self learning (Long, 1991; Pao-NanveWei-Fan, 2008) is in relationship with the academic achievement in some samples of traditional classrooms; it is not in relationship with academic achievement in some samples. (Candy, 1991). Furthermore, Shinkareva and Benson (2007) stated that there is a relationship between self learning levels of the students and utilization of technology in the lessons, but there is not any positive relationship between self learning levels and academic achievement in these lessons (Pao-Nan \& Wei-Fan, 2008). Nevertheless, theorical discussions and experimental findings show that in terms of both applicated teaching tecniques and individual differences of self learning process should be taken into consideration (Brockett\&Hiemstra, 1991; Long, 1990).

Therefore, the affect of e-learning improvement in self learning process and presentation of e-learning as an education system can be evaluated in terms of the students' attributes and the harmony of the applied teaching methods. Hence, a succesfull student should have the characteristics such as self motivation, patience, self discipline, competence in using computer software, time management, tecnical skills about communication and organization. These attributes directly effect the e-learning attitudes of the students towards cooperation. According to Reio and Davis (2005), the utilization of the teaching methods and techniques providing the students self learning promotes feedback about the learning materials and processes used by the students and learned from each other (as cited in Aydede $\&$ Kesercioğlu, 2009). In their investigation, EL-Deghaidy and Nouby (2008) found that there are positive and significant relationship between teachers' attitudes towards e-learning and cooperative learning. In view of researches above, knowledge and skills in self learning 
of the high schools students are very important in terms of their cooperative e-learning attitudes. As a result of this literature review, there are several researches related to the attitudes of the students towards to e-learning (Ajadi, Salawu, \& Adeoye, 2008; Bertea, 2009; Kar, Saha \& Mondal, 2014; Lertlum \&Papasratorn, 2004; Rhema \& Miliszewska, 2010; Tuparova, et al., 2006). However, as there is not any investigation about students' cooperative e-learning in the process of self learning process, it is supposed that conducting an investigation about this subject will be a source further researches. In the view of this literaturein this survey, the aim of this research is to investigate if there is any positive and significant the relationships between e-learning and cooperative learning attitudes of the high school students. In accordance with this aim, the question "what kind of relationship is present between the attitudes of the students at high schools towards to e-learning and the attitudes of the students at high schools towards cooperative learning?" is searched for an answer.

\section{Method}

\section{Research Model}

Relational screening model one of the relational survey model was utilized in this survey. According to Karasar (2006), Relational screening model is a kind of model that aims to determine the presence and/or degree among two and more variances together. In the scope of scanning model, cooperative learning scale was applied together with e-learning attitude scale to the students.

\section{Research Group}

The universe of this survey comprises of the students who study at three different high schools in the central counties of the province of Sakarya. The sample of the study includes 415 students (215 female 51\%, 200 male 49\%) who study Physics, Chemistry, Biology and Maths in the randomly selected Science High School, Anatolian High School and Business High School. Sample three were 150 (36\%) Science High School students (80 male, 70 female), 165(40\%) Anatolian High School students (75 male, 90 female), 100 (24\%) Business High School students (65 male, 35 female) who enrolled in study.

\section{Data Collection Tools}

E-LearningAttitudeScale: E-learning attitude scale comprises of 24 items with 5 Likert and adapted to Turkish language byKurbanoğlu and his collegues (2010). E-learning attitude scale has two sub-dimensions. The first sub dimension generally measures "e-learning attitude" and the second sub dimension measures "e-learning about the science lessons". Elearning attitude sub dimension in the scale comprises of 12 (6 positive and 6 negative) items (example; when I use e-learning techniques, I get the all control; dealing with e-learning techniques worries me). E-Learning about the science lessons sub dimension comprises of 12 (6 positive and 6 negative) items (example; I want to learn science lessons via e-learning; I worry about the presentation of the science lessons in electronic media). Possible total score intervals from the scale varies between 24 and 120. Reliability factor of Turkish form of the scale was found as .85. Itemtotal correlation of the scale is between .35 and .87 .

Cooperative Learning Scale: Cooperative Learning Scale was developed by ELDeghaidy and Nouby (2008). Cooperative Learning Scale comprises of 20 items with 5 Likert (10 positive, 10 negative). Example, "Involvement in joint projects is very satisfying" is a positive item; "It is difficult to arrive at an agreed decision, in groups" is a negative item. Possible total score intervals from the scale varies between 20 and 100 . Reliability and validity research of the scale was performed on the sample of the recent survey. Therefore, reliability factor of Turkish version of the scale was found as .73. 


\section{INVESTIGATION OF THE RELATIONSHIP BETWEEN E-LEARNING AND COOPERATIVE LEARNING ATTITUDES OF HIGH SCHOOL STUDENTS}

\section{Analysis of Data}

The participants of the survey were selected by the use of purposive sampling technique. Purposive sampling technique is one of the non-random sampling techniques and the researcher selects the most appropriate and accessible participants for himself. The students who were selected for the sample group filled the questionnare anonymously. Collected data were analysed with the use of correlation and structural equation modeling.

\section{Findings}

In this study, it is aimed to determine whether there is a significant relationship between e-learning attitude and cooperative learning attitude of the high school students who are in the process of high school period. Results of correlation analyses of the present research were given in Table 1 .

Table 1 . The results of correlation analiyses between the variables

\begin{tabular}{llll}
\hline Variables & E-learning & $\begin{array}{l}\text { E-learning towards science } \\
\text { lessons }\end{array}$ & Cooperative learning \\
\hline E-learning & 1 & & \\
E-learning towards science & $.57 * *$ & 1 & 1 \\
lessons & $.51^{* *}$ & $.49 * *$ & 61.1 \\
Cooperative learning & 33.8 & 34.7 & 9.5 \\
Mean & 5.6 & 5.9 & \\
Standard Dv. & &
\end{tabular}

According to results of correlation analiyses, it was found that there is a positive relationship between the students' e-learning attitude scores $(\mathrm{r}=.51)$ and cooperative learning scores, and there is a positive relationship between e-learning attitude scores towards to science lessons and cooperative learning scores $(r=.49)$.

\section{Structural Equation Modeling}

The collected data were analysed by the use of structural equation modeling in order to determine whether students' e-learning attitudes predicts their cooperative learning attitudes. The result of the analyse was demonstrated in Figure 1.

The findings which are acquired from the structural equation modeling demonstrating the prediction of cooperative learning for e-learning shows that the model is well oriented $(\chi 2=4862.18, \mathrm{sd}=899, \mathrm{NNFI}=.83, \mathrm{CFI}=.84, \mathrm{IFI}=.84, \mathrm{SRMR}=.009, \mathrm{RMSEA}=.103)$. According to these results, cooperative learning explains $26 \%$ of e-learning ( $R 2=.26, F(1$, $413)=150.237, \mathrm{p}<.01$ ), and cooperative learning explains $6 \%$ of e-learning about science lessons $(\mathrm{R} 2=.6, \mathrm{~F}(2,412)=98.56, \mathrm{p}<.01)$. Cooperative learning predicts e-learning attitude sub dimension utmost. Consequently, cooperative learning explains $32 \%$ of e-learning and elearning about science lessons. 

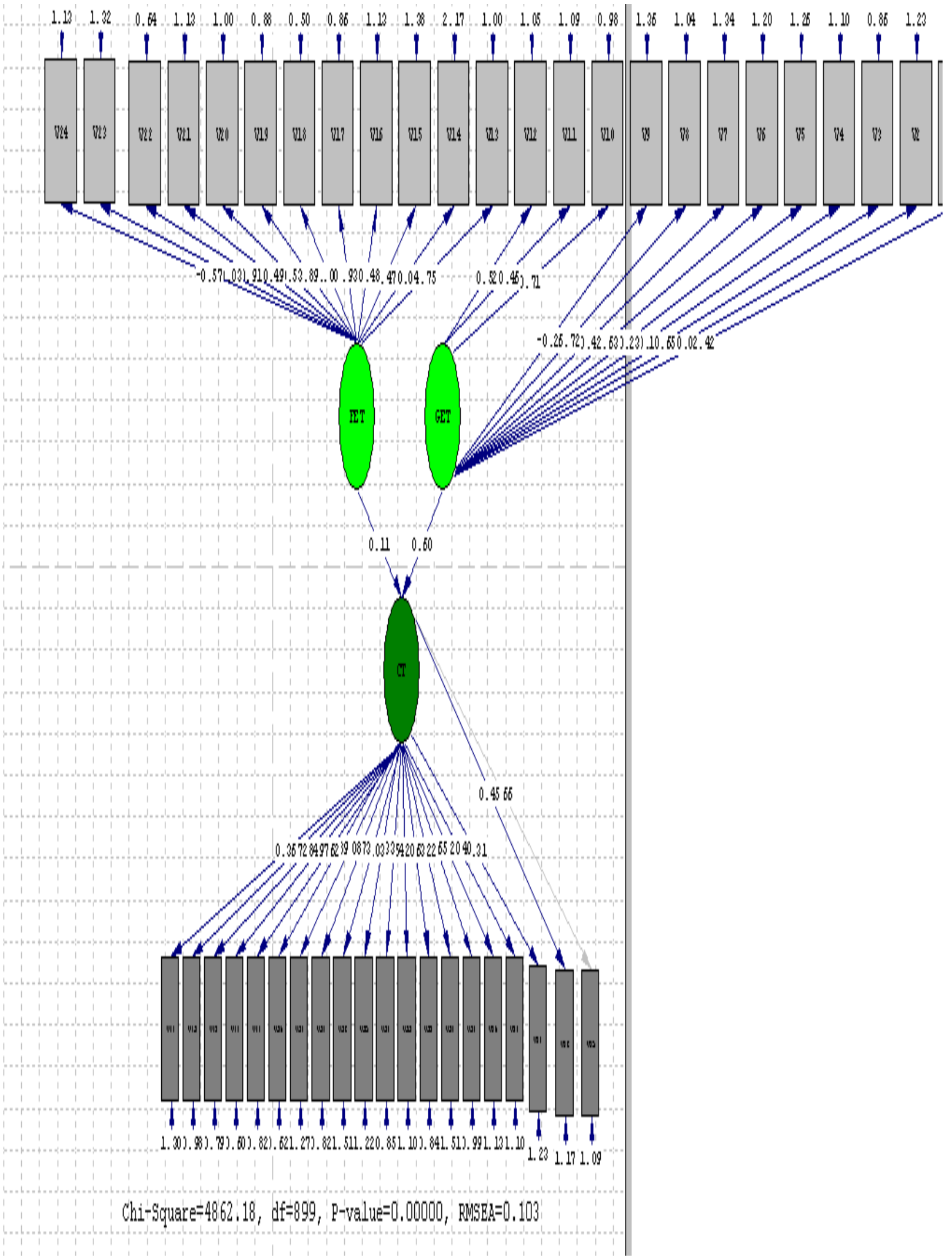

Figure 1. Path Analyse about the relationships between e-learning and cooperative learning $(\mathrm{p}<.05)$. 


\section{INVESTIGATION OF THE RELATIONS HIP BETWEEN E-LEARNING AND COOPERATIVE LEARNING ATTITUDES OF HIGH SCHOOL STUDENTS}

\section{Discussion and Conclusions}

In the present research, it is determined whether there is a significant relationship between e-learning attitude and cooperative learning attitude of the high school students. The analyse results of the collected data in the survey demonstrated that there is a positive and significant relationship between high school students' e-learning attitude scores and cooperative learning attitude scores $(\mathrm{p}<.01)$.This relationship is at the medium-level. When the high school students' e-learning attitude scores increase, cooperative learning scores increase. The reason of this increase in the e-learning attitude score is considered that cooperative learning effectsstudents' e-learning attitudes positively towards science lessons. The results of the surveys in this field show that there is a positive relationship between $\mathrm{e}$ learning and cooperative learning.

EL-Deghaidy and Nouby (2008) found in their investigation to determine the relationship between teachers' e-learning attitude and cooperative learning attitude found that e-learning attitude scores of the teachers in the experiment group were higher than the scores of cooperative learning. It was found that the teachers' e-learning attitude scores in the experiment group were higher than the scores of control group teachers'. Furthermore, findings acquired from the structural equation modeling demonstrated that cooperative learning predicted the sub dimensions of e-learning positively. In the study of Freishtat and Sandlin (2010), they emphasized that the educational technologies which are taken into consideration as e-learning such as cooperative learning, peer learning were very important for the activities run by the students and they can improve the learning environments. Besides, effective learning environments help students and teachers to improve their knowledge and they are alsoso important in order to develop beneficial knowledge for the community. Positive cooperative e-learning results in a beneficial interaction for the individuals in the learning process.

E-learning in cooperation can be provided by determining common objects, distribution of tasks, work sharing and group identity (EL-Deghaidy \& Nouby, 2008). In another investigation, Sutton (1991) found that cooperative student groups showed more positive attitudes than individual groups in the computer based lessons and e-learning processes. In the research, engineering and health science students demonstrated negative attitudes of elearning process of cooperative learning (Keller \&Cernerud, 2002). In a study of Mandl and Krause (2003), they found that as e-learning facilitated self regulated learning, e-learning is a good way of supporting the students individually even in negative learning conditions. Chang and Chen (2009) suggested cooperative learning methods and peer evaluation system as equalitarian and democratic methods in order to evaluate peer works in e-learning environments. In addition, Wahab (2008) argued that students make information permanent by modeling learning through collaborative learning using communication technologies. Students have realized that cooperative learning and e-learning are essential for success in school life. Also, the e-learning environment supported by collaborative learning can make a difference by providing students with appropriate educational environments in a way that increases the ease of use of communication technology. In another study, the assessments made in the research (Gönen, Kocakaya \& İnan, 2006), it was determined that The use of new technologies should be encouraged in the implementation of the constructivist approach model. Learning environments should be supported by new technologies to provide students with a better learning quality. Similarly, Morgil et al. (2008) observed that students had unlimited repetition by using web technologies, increasing their interest in Visual features and learning. These results support the findings of the study.

Consequently, in the present research it was found that there is a positive and significant relationship between students' e-learning attitude scores and cooperative learning attitude scores, and cooperative learning predicts positively sub dimensions of e-learning. The participants of this research comprise of high school students and this situation prevents generalizing the results of the research to different age groups. This investigation can be applied on different age groups and larger samples. Moreover, as the present research's analyses are performed by the use of structural equation modeling, cause and effect relationship is not possible. It is considered that further experimental investigations would promote the findings of the present research. In addition, More studies can be done using 
different variables and different samples to provide a better perspective on research questions. Future research can be applied in different cultures and samples to contribute to the generalization of the results of the research.

\section{References}

Ajadi, T., Salawu, O., \& Adeoye, F. (2008). E-learning and distance education in Nigeria. The Turkish online journal of educational technology, 7(4), 61-70.

Anderson, J. (2005). IT, e-learning and teacher development. International Education Journal, 5(5), $1-14$.

Angelini, A., Gentile, E., Plantamura, P., \& Plantamura, V. L. (2005). Web Information Systemfor eLearning. International Academy of Sciences: Enformatika, 8, 209-212.

Aşkar, P. (2003). Uzaktan ĕgitimde temel yaklaşımlar ve uzaktan eğitimde öğrenci (katılımcl) olmak. Uzaktan Eğitim Teknolojileri ve TCMB'de Teknoloji Destekli Bilgisayar Eğitimi Konferans1, 31 Ekim 2001. Ankara: TCMB. 3-40.

Aydede, M8. N. \& Kesercioğlu, T. (2009). Fen ve teknoloji dersine yönelik kendi kendine öğrenme becerileri ölçeğinin geliştirilmesi. Çukurova Üniversitesi Ĕ̈itim Fakültesi Dergisi, 3(36), 53-61.

Aydede, M. N. \& Kesercioğlu, T. (2012). Aktif öğrenme uygulamalarının öğrencilerin kendi kendine öğrenme becerilerine etkisi. Hacettepe Üniversitesi Eğitim Fakültesi Dergisi (H. U. Journal of Education), 43, 37-49.

Bedard, R. (1997). Self-directed learning in thenextcentury: What should theorientation be? In H. Long (Ed.), Expandinghorizons in self-directed learning (pp. 281-291). Norman, OK: University of Oklahoma College of Education Public Managers Center.

Bertea, P. (2009). Measuring students' attitude towards e-learning. A case study. The 5th International Scientific Conference e-Learning and Software for Education. Bucharest, April 0910.

Brockett, R. G.\&Hiemstra, R. (1991). Self-direction in adult learning: Perspective on theory, research, and practice. New York, NY: Routledge.

Butzin, S. M. (2000). Using instructional technology in transformed learning environments: An evaluation of projectchild. Journal of Research in Educational Computing Education, 33(4), $367-384$.

Büyükkaragöz, S. S. \& Çivi, C. (1999). Genel ögretim metotları. Özel eğitim yayınları, İstanbul.

Candy, P. (1991). Self-direction for life long learning: A comprehensive guide to theory and practice. San Francisco: Jossey-Bass.

Chang, T. Y. \& Chen, Y. T. (2009). Cooperative learning in E-learning: A peer assessment of studentcentered using consistent fuzzy reference. Expert Systems with Applications, 36, 8342-8349.

Eisenman, G. (1990). Self-directed learning-A growth process? In H. Long (Ed.), Advances in research and practice in self-directed learning (pp. 93-122). Norman, OK: Oklahoma Research Center for Continuing Professional and Higher Education.

EL-Deghaidy, H. \&Nouby, A. (2008). Effectiveness of a blended e-learning cooperative approach in an Egyptian teacher education programme. Computers \& Education, 51, 988-1006.

Erdemir, N., Bakırc1, H. \& Eyduran, E. (2009). Öğretmen adaylarının eğitimde teknolojiyi kullanabilme özgüvenlerinin tespiti. Türk Fen Eğitimi Dergisi (TÜFED-TUSED), 6(3), 99-108.

Francis, A. \& Flanigan, A. (2012). Self-directed learning and higher education practices: implications for student performance and engagement. The International Journal of the Scholarship of Teaching and Learning, 7(3), 1-18.

Freishtat, L. R. \& Sandlin, A. J. (2010). Shaping youth discourse about technology: Technological colonization, manifest destiny, and the frontier myth in facebook's public pedagogy. Educational Studies, 46(5),503-523.

Ghani, N. A., Hamim, N., \& Ishak N. (2007). Web-based learning in science education: overview and implementation for primary school in Malaysia. International Conference on Education 2007 Universiti Brunei Darussalam.

Goetsch, D. L. (1984). Impact of technology on curriculum and delivery strategies in vocational education in Shulman, Carol Herrnstadt. (Ed.) Adultsand the Changing Work place. American Vocational Association, Inc., 191-200. 


\section{INVESTIGATION OF THE RELATIONS HIP BETWEEN E-LEARNING AND COOPERATIVE LEARNING ATTITUDES OF HIGH SCHOOL STUDENTS}

Gönen, S., Kocakaya, S. \& İnan, C. (2006). The effect of the computer assisted teaching and 7e model of the constructivist learning methods on the achievements and attitudes of high school students. The Turkish Online Journal of Educational Technology,5(4), 82-88.

Grow, G. O. (1991). Teaching learners to be self-directed. Adult Education Quarterly, 41, 125-149.

Halis, İ. (2001). Öğretim teknolojileri ve materyal geliștirme. Konya: Mikro Yayınları.

Hızal, A. (1977). Programlı ögretim. A.Ü., Basımevi, Ankara.

Hiemstra, R. (2004). Self-directed learning lexicon. International Journal of Self-Directed Learning, $1,1-6$.

Hopson, M. H., Simms, R. L., \& Knezek, G. A. (2002). Using a technologically enriched environment to impro ve higher-order thinking skills. Journal of Research on Technology in Education, 34(2), 109-119.

Kar, D., Saha, B., \& Mondal, B. C. (2014). Attitude of university students towards e-learning in West Bengal. AmericanJournal of Educational Research, 2 (8), 669-673.

Karasar, N. (2006). Bilimsel araştırma yöntemi (16. Baskı). Ankara: Nobel Yayın Dağıtım.

Kasworm, C. E. (1992). Adult learners in academic settings: Self-directed learning within the formal learning context. In H. Long (Ed.), Self-directed learning: Application and reseach (pp. 223-244) Norman, OK: Oklahoma Research Center for Continuing Professional and Higher Education.

Keller, C. \& Cernerud, L. (2002). Students' perceptions of e-learning in university education. Journal of Educational Media, 27.

Knowles, M. (1975). Self-directed learning: A guide for learners and teachers. New York: Association Press.

Kurbanoğlu, N. İ., Takunyaci, M., Kocaman, O. ve Çetinkaya, G. (2010). The Turkish adaptation ofelearning attitude scale: Reliability and validity studies. 10th International EducationalTechnology Conference (IETC-April 26-28), Istanbul, TURKEY.

Lertlum, W. \& Papasratorn, B. (2004). Trust framework for web-based learning system. Proceeding of The International Conference on PISTA' 04 and CITSA'04. Orlando, USA, July 21-25.

Lertlum, W. \& Papasratorn, B. (2006) Factors influencing rote learner's intention to use WBL: developing country study. International Journal of ComputerScience, 1(1).

Long, H. B. (1989). Self-directed learning: Emerging theory and practice. In H. Long (Ed.), Emerging theory and practice (pp. 1-11). Normal, OK: Oklahoma Research Center for Continuing Professional and Higher Education.

Long, H. B. (1990). Changing concepts of self-direction in learning. In H. Long (Ed.), Advances in research and practice in self-directed learning (pp. 1-7). Norman, OK: Oklahoma Research Center for Continuing Professional and Higher Education.

Long, H. B. (1991). College students' self-directed learning readiness and educational achievement. In H. Long (Ed.), Self-directed learning: Consensus \& conflict (pp. 107-122). Norman, OK: Oklahoma Research Center for Continuing Professional and Higher Education.

Long, H. B., Redding, T. R., \& Eisenman, G. (1994). A longitudunal study: Socialbehavior and sdlrs scores. In H. Long (Ed.), New ideasabout self-directedlearning (pp. 39-57). Norman, OK: Oklahoma Research Center for Continuing Professional and Higher Education.

Mandl, H. \& Krause, U.-M. (2003). Learning competence for the knowledge society. In N. Nistor, S. English, S. Wheeler \& M. Jalobeanu (Eds.), toward the virtual university International online perspectives (pp. 65-86). Greenwich, CT: Information Age Publishing.

Middlehurst, R. (1999). New realities for leadership and governance in higher education? Tertiary Educationand Management, 5, 307-329.

Nichols, M. (2003). A theory for e-learning. Retrieved March 8, 2016, from http://www.ifets.inf/journals/6_2/1.pdf.

Pao-Nan, C. \& Wei-Fan, C. (2008). Exploratory study of the relationship between self-directed learning and academic performance in a web-based learning environment. Online Journal of DistanceLearningAdministration, 11 .

Pilling-Cormick, J., \& Garrison, D. R. (2007). Self-directed and self-regulated learning: Conceptual links. Canadian Journal of University Continuing Education, 33, 13-33.

Piskurich, G. M. (1992). Preparing the learner for self-directed learning. In H. Long (Ed.), Selfdirectedlearning: Application and reseach (pp. 309-321). Norman, OK: Oklahoma Research Center for Continuing Professional and Higher Education. 
Reio, T. G. \& Davis, W. (2005). Age and gender differences in self-directed learning readiness: a developmental perspective. International Journal of Self-directed Learning, 2(1), 40-49.

Reiser, R. A. (2001). A history of instructional design and technology: Part 1: A history of instructionalmedia. Educational Technology Researchand Development, 49 (1), 53-64.

Rhema, A \&Miliszewska, I. (2010). Towards e-learning in higher education in Libya. Issues in InformingScienceand Information Technology, 7, 423-437.

Ruiz, J. G., Mintzer, M. J., \& Leipzig, R. M. (2006). The Impact of e-learning in medical education. Academic Medicine, 81(3), 207-212.

Russell, A. T., Comello, R. J. \& Wright, D. E. (2007). Teaching strategies promoting active learning in healthcare education. Education and Homan development, 1(1), 1-8.

Sam, H. K., Othman, A. E. A., \& Nordin, Z. S. (2005). Computer self-efficacy, computer anxiety, and attitudes toward the internet: A study among undergraduates in unimas. Educational Technology \& Society, 8(4), 205-219.

Shinkareva, O. N. \& Benson, A. D. (2007). The relationship between adult students' instructional technology competency and self-directed learning ability in an online course. Human Resource Development International, 10, 417-435.

Stark, R. \&Mandl, H. (2000). Training in empirical research methods: Analysis of problems and intervention from a motivational perspective. In J. Heckhausen (Ed.), Motivational psychology of human development (pp. 165-183). Elsevier: Amsterdam.

Sutton, R. (1991). Equity and computers in the schools: A decade of research. Review of Educational Research, 61(4), 475-503.

Tuparov, G., Tuparova, D., Ivanov, S., Karashtranova, E., \& Peneva J. (2006). Teachers' attitude towards e-learning courses in Bulgarian universities. Current Developments in TechnologyAssisted Education", pp. 1755-1759, IV International Conference on Multimedia and Information and Communication Technologies in Education, Seville, Spain.

Wahab, A.G.A. (2008). Modeling students' intention to adopt e-learning: A case from Egypt. The Electronic Journal of Information Systems in Developing Countries, 34(1), 1-13.

Waller, V. E-learning Network \& J. Wilson, The Forum forTechnology in Training, (2001). Open and distance learning quality council (ODLQC). Newsletter. A definition for e-learning.

Williams, H. S. \& Kingham, M. (2003). Infusion of technology into the curriculum. Journal of Instructional Psychology, 30(3), 178-184. 
